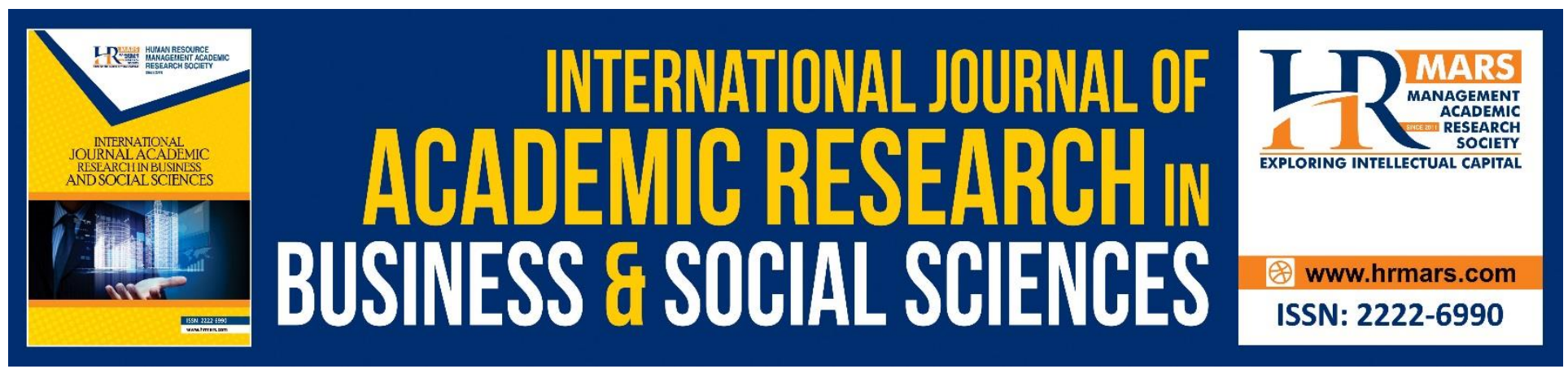

\title{
The Concept of Human Will According to Al-Ghazali and Abraham Maslow: A Comparative Study
}

Norhashimah Yahya, Omar S.H.S., Mohammed Muneer'deen Olodo AlShafi'l, Mohd Shaifulbahri Abdullah, Mohd Safri Ali, Engku Ibrahim Engku Wok Zin

To Link this Article: http://dx.doi.org/10.6007/IJARBSS/v8-i10/4715 DOI: $10.6007 /$ IJARBSS/v8-i10/4715

Received: 11 Sept 2018, Revised: 15 Oct 2018, Accepted: 17 Oct 2018

Published Online: 30 October 2018

In-Text Citation: (Yahya et al., 2018)

To Cite this Article: Yahya, N., Omar, S. H. ., Al-Shafi'I, M. M. O., Abdullah, M. S., Ali, M. S., \& Zin, E. I. E. W. (2018). The Concept of Human Will According to Al-Ghazali and Abraham Maslow: A Comparative Study. International Journal of Academic Research in Business and Social Sciences, 8(10), 91-99.

Copyright: (C) 2018 The Author(s)

Published by Human Resource Management Academic Research Society (www.hrmars.com)

This article is published under the Creative Commons Attribution (CC BY 4.0) license. Anyone may reproduce, distribute, translate and create derivative works of this article (for both commercial and non-commercial purposes), subject to full attribution to the original publication and authors. The full terms of this license may be seen

at: http://creativecommons.org/licences/by/4.0/legalcode

Vol. 8, No. 10, 2018, Pg. 91 - 99

http://hrmars.com/index.php/pages/detail/IJARBSS

JOURNAL HOMEPAGE

Full Terms \& Conditions of access and use can be found at http://hrmars.com/index.php/pages/detail/publication-ethics 


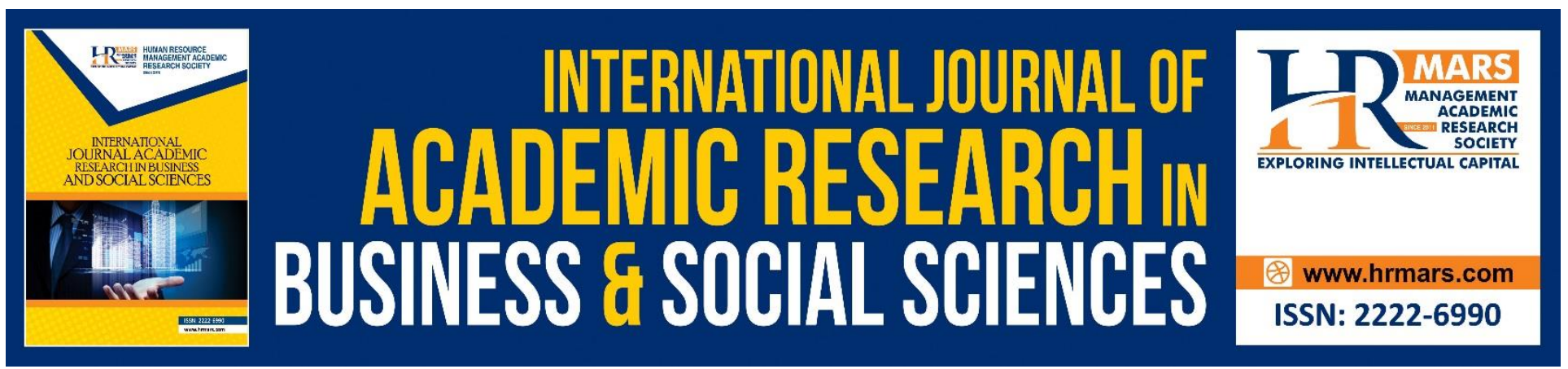

\title{
The Concept of Human Will According to Al-Ghazali and Abraham Maslow: A Comparative Study
}

\author{
Norhashimah Yahya \\ PhD Candidate, Department of Usuluddin, Faculty Islamic Contemporary Studies, Universiti Sultan \\ Zainal Abidin (UniSZA), Terengganu, Malaysia. \\ Omar S.H.S. \\ (Corresponding author) \\ Department of Usuluddin, Faculty Islamic Contemporary Studies, \\ Universiti Sultan Zainal Abidin (UniSZA), Terengganu, Malaysia. \\ Email: sylutfi@unisza.edu.my
}

\begin{abstract}
Mohammed Muneer'deen Olodo Al-Shafi'l, Mohd Shaifulbahri Abdullah, Mohd Safri Ali, Engku Ibrahim Engku Wok Zin

Department of Usuluddin, Faculty Islamic Contemporary Studies, Universiti Sultan Zainal Abidin (UniSZA), Terengganu, Malaysia.
\end{abstract}

\begin{abstract}
The concept of human will is one of the key elements that need to be discussed in identifying one's direction in life. Every human action is born out from his will. The concept of human will presented by Abraham Maslow is found to fulfil the necessity of life alone and is unable to achieve human satisfactions. Therefore, the position of the concept of the will of every individual is a priority highlighted in academic studies. This paper discusses the concept of human will according to alGhazali and Abraham Maslow, comparing the various elements highlighted by the two figures concerning human will. The study uses qualitative approach and content analysis method, and finds that the concept of human will discussed by al-Ghazali and Maslow are similar in terms of fulfilling the needs of humanity. The difference therein is noticed in terms of the means to meet those requirements to achieve self-satisfaction, the concept of acceptance and ultimate happiness.
\end{abstract}

Keywords: Al-Ghazali, Human Will, Maslow, Hierarchy Of Human Needs. 


\section{INTRODUCTION}

The term 'will', according to Kamus Dewan, the fourth edition, is inner intentions, decisions and desires (Baharom, 2007). The concept of will is also discussed as such in psychology, and Western scholars also do not deny the existence of human will. In fact, this will have relative relevance to responsibility. The will is often considered subjective because the requirement is largely related to the internal and external factors of the nature of instincts, passions, objectives, encouragement, suggestions, benefits, rejection, understanding, rationale and trust (Atiullah, Indriaty, \& Ibrahim, 2014).

Everyone have his own will, however, just when a desired will is fulfilled another one starts. This shows that human will never cease, a position equally maintained by Abraham Maslow (1970), a Western psychologist, around 1970. Even in fulfilling the necessities of life, it is self-reliant. This proves that humans experience conflict in dealing with self-will, particularly in meeting up with life expectations. The writers therefore find that a proposed solution has to be put forward to limiting the conflict, in order to meet up with life expectations.

\section{AL-GHAZALI'S CONCEPT OF HUMAN WILL}

The concept of human will, from the perspective of al-Ghazali, is a natural desire and love deeply rooted in one who wishes to achieve everlasting happiness while meeting Allah s.w.t, until all kinds and levels of worldly enjoyment becomes tasteless to him (al-Ghazali, 1975, Omar et al., 2017). AlGhazali further states that the lack of faith in Allah s.w.t is a major obstacle to one's attainment of human will (al-Ghazali, 1975).

The term 'faith' decided by al-Ghazali is not merely the pronouncement al-Shahadah (testifying that Allah is One and Muhammad is His Messenger), rather it must be accompanied with honesty (al-Sidq) and sincerity (al-Ikhlas) (al-Ghazali, 1975). The similarity between the faith that is merely a lip-service and a sincere-hearty testification is like that of one who says "diamond gems are more valuable than crystal gems" without knowing what exactly diamond gems are.

Similarly, the possibility of having diamond gems is slim because people are accustomed to wearing crystal gems (al-Ghazali, 1975). It should be understood therefore that the faith in Allah s.w.t in all honesty and sincerity is the root of human will in that context (al-Ghazali, 1975).

Al-Qaradawi, a well-known scholar, emphasizes the need for Muslims to understand the true concept of faith of the righteous predecessors, which is accompanied with the conviction of the heart, sincerity and obedience to Allah s.w.t in the same way (al-Qaradawi, 1987). In fact, the concept of faith is not merely a cognitive knowledge achieved theoretically without the conviction in attaining certainty (Hamat, 2002). Al-Ghazali's concept of human will could be represented as in the following diagram:

The authors explain that human being can achieve ultimate happiness through human will (box A). In other words, the main goal of man in life is to achieve happiness, and the ultimate happiness for man is that in the hereafter. In addition, the achievement of human will must be accompanied with faith in Allah s.w.t. As mentioned earlier, faith is a condition for one to attain one's human will (box B). 
INTERNATIONAL JOURNAL OF ACADEMIC RESEARCH IN BUSINESS AND SOCIAL SCIENCES Vol. 8, No. 10, Oct. 2018, E-ISSN: 2222-6990 @ 2018 HRMARS

In addition, in order to achieve the ultimate happiness it is also necessary to integrate knowledge with practice (box C) to produce behaviour that is based on Shari'ah. The behaviours resulted must also lead to the objective of human will. The Islamic Shari'ah, established by Allah s.w.t is the most organized rule, and it is based on human capacity and ability.

Furthermore, the lack or the absence of faith is one of the obstacles to fulfilling human will for achieving ultimate happiness (box D). The effects of lack or absence of faith subjects people to misery in a later period.

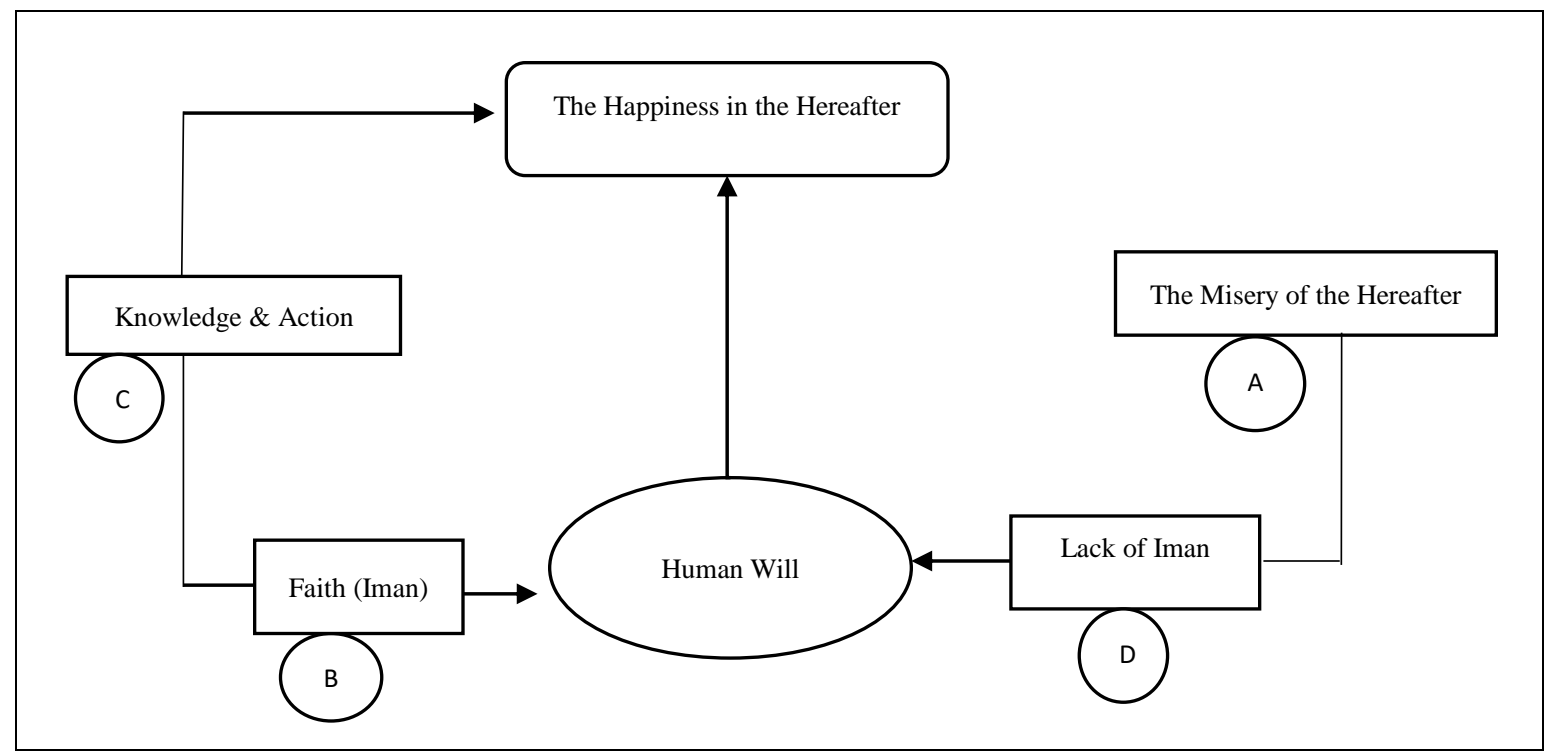

Figure 1: The concept of human will according to al-Ghazali

\section{MASLOW'S CONCEPT OF HUMAN WILL AND LIFE}

Maslow gives priority to the aspect of human development in his humanistic theory. Human development, according to Maslow, is dictated by human developmental and living necessities. In other words, human beings are more motivated and self-satisfied when their basic needs are fulfilled. This theory also focuses on moral readiness and potentiality (Nor Nazimi et al., 2017).

In addition, humanistic theories also focus on individual's self-awareness; the uniqueness and interests of the individual. This theory prioritizes humans as leaders and decision makers. Among humanistic concepts of Maslow (1943) is that when one achieves self-perfection, one is capable of meaningful self-potentiality. This is because of Maslow's view that man has the inner power to produce the maximum self-potential known as 'self-actualization' (Zainal, 2008).

The humanistic theories of Maslow are closely related to the hierarchy of living requirements he introduced. The hierarchy is also known as the human need pyramid theory, which comprises the basic level of human needs and individual goals (Nor Nazimi et al., 2017). When those needs are fully met, individuals can then directly self-motivate themselves to a higher level, especially to achieve self-perfection. In a like manner, if those needs are not reliably met, human soul would be disturbed and filled with uncertainty. The hierarchy of human needs from physiological, safety, social/love, selfesteem and self-actualization are as stated in figure 2 below. 


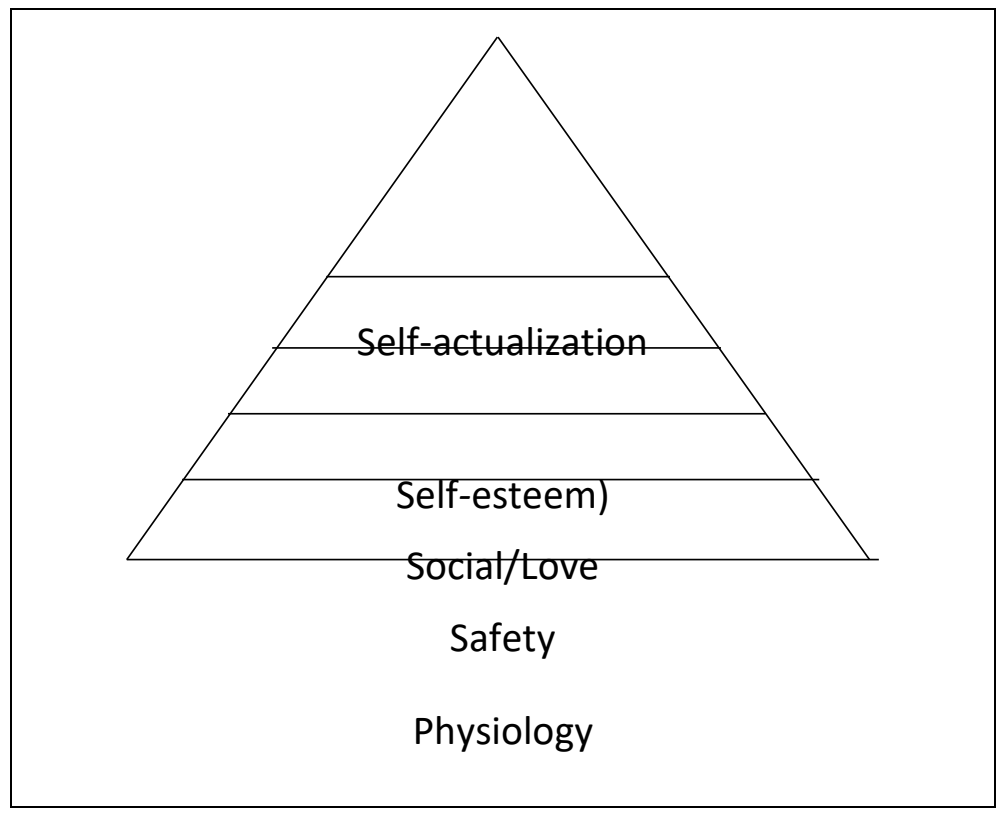

Figure 2: Maslow's hierarchy of living needs

Although Maslow does not give a specific definition of human will, the essence of his stated desires especially to meet the needs of life gives a clear meaning that man has the will of fulfilling the necessities of life. Even the desire also brings meaning to the will. Man can achieve it when motivated by motivational elements. This is because motivation is also described as a necessity, a desire, which functions to activate energy to behaviour and give direction (Maslow, 1970; Huitt, 2001).

Woolfolk (1998) also argues that human will is motivated by motivation to do well. Amla and Zuria also support this view when they maintain that motivation can be seen from the behavioural characteristics that depict one's feelings and emotions (Amla \& Zuria, 2005). Below is Maslow's thinking framework regarding the concept of living necessities.

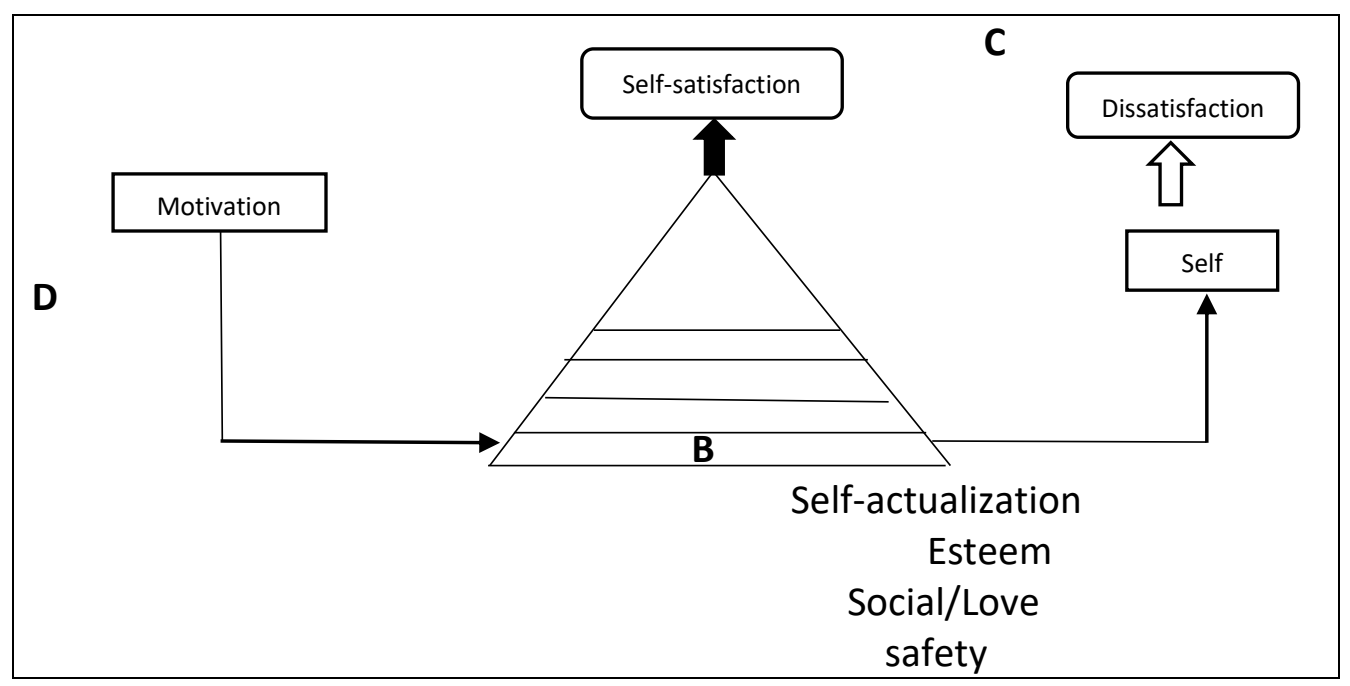


INTERNATIONAL JOURNAL OF ACADEMIC RESEARCH IN BUSINESS AND SOCIAL SCIENCES Vol. 8, No. 10, Oct. 2018, E-ISSN: 2222-6990 @ 2018 HRMARS

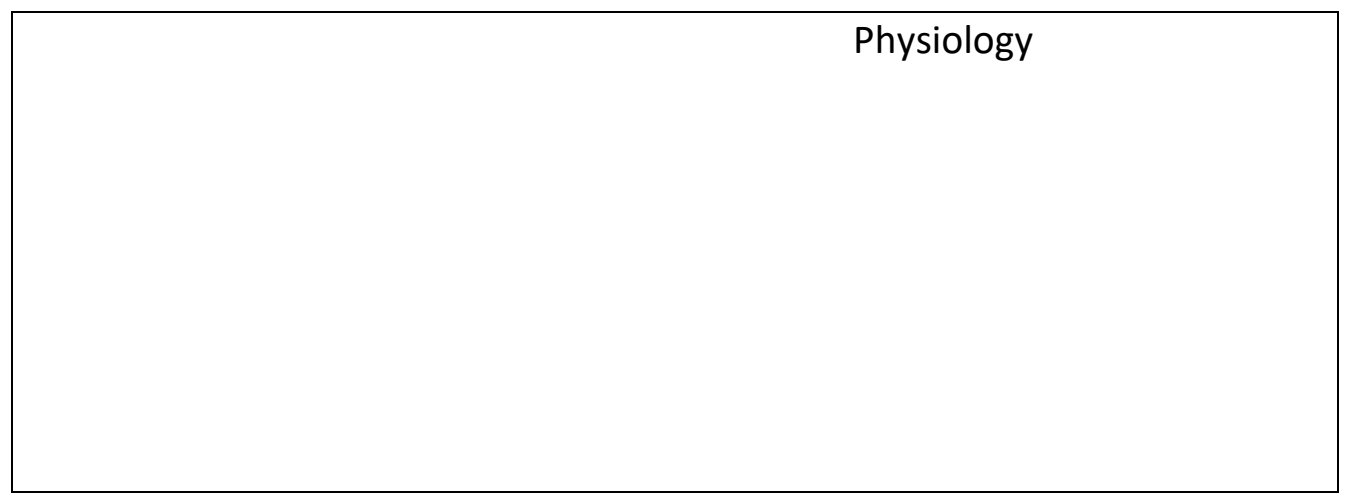

Figure 3: Maslow's concepts of human needs

This figure starts from (arrow A) where motivation is needed to meet the life necessities. The living necessity hierarchy (symbol $B$ ) is a requirement hierarchy proposed by Maslow, consisting of physiological, safety, social, personal and self-improvement needs. When man meets the very need of self-perfection, it is only self-satisfying (symbol C). However, most people acquire these necessities through lust, and therefore results into dissatisfaction (arrow D) for them.

\section{SIMILARITIES AND DIFFERENCES BETWEEN AL-GHAZALI AND MASLOW'S CONCEPT OF HUMAN NEEDS}

The authors examine the difference in physiological needs of Maslow and al-Ghazali, and found out that there is no correlation between the Western psychological thoughts that man needs to meet physiological needs before progressing to the next stage. This is because some have argued that it is not necessary that man fulfils the physiological needs before moving to another level. This could be so because of their perception that man is a unique creature having his own potential. It is true that everyone has his own level of satisfaction; while some find it difficult getting satisfaction through physiological needs, some others are easily satisfied with what they have. In other words, the necessary physiological needs are sufficient for them for survival.

This, however, is an important aspect to be aware of in the Islamic tenets. This is because, if man cannot meet the necessary needs, his will may be hindered. And when the will is hindered, a non-believing lust will dominate and thus expose man to evil acts.

For example someone who wants to achieve his will in a short time. Such a person could engage in stealing or taking someone else's rights. Stealing is prohibited in Islam because it violates Islamic Shari'ah. Hence, fulfilling physiological requirements is just enough and prudent is one of the best ways to ensure that desired needs are not beyond the boundaries of the established shari'ah.

\section{CONCLUSION}

Therefore, in order to fulfil such, desires need to be balanced and consistent with human wellbeing in terms of spirituality. In addition, it should be through integrated knowledge, planning, diligence, trust, patience and prayer and accompanied with tawhid. These are important in a one's quest to fulfil the necessity of life in line with human desire that every action that is being implemented does not necessarily violate the limits of Shari'ah. 
Furthermore, self-perfection in Islam emphasizes that self-awareness is the perfection of self and the purpose of life, i.e. returning to back to the primordial acknowledgement of the oneness of Allah s.w.t. as the Creator. In addition, self-conscious people will be able to develop their potential, especially in spiritual development.

Maslow maintains that man has internal strength to acquire maximum potential to achieve self-perfection. The potential of the self also gives meaning to self and human life.

On the other hand, according to table 1 below, physiological needs are basic necessity for man and an important aspect of survival. In fact, in human efforts to ensure social well-being, it is certain that humans cannot do without fulfilling the needs of their lives especially in relation to basic needs (Haris, 2010). Thus, the hierarchy introduced by Maslow places social needs at a higher level than physiological needs, which means that man can successfully fulfil his physiological needs, and has a positive impact in ensuring his social well-being.

\begin{tabular}{|c|c|c|c|}
\hline Element & Al-Ghazali & Maslow & Comparison \\
\hline Necessity of life & $\begin{array}{l}\text { Physiology } \\
\text {-Basic life needs, such } \\
\text { as food, clothing, and } \\
\text { shelter are just } \\
\text { enough. } \\
\text {-No } \\
\text { extravagances/waste. } \\
\text { Safety } \\
\text {-Religious protection } \\
\text {-Personel protection } \\
\text {-Intellectual } \\
\text { protection } \\
\text {-Lineage protection } \\
\text {-Property protection } \\
\text { Social } \\
\text { Livelihood depends on } \\
\text { Allah s.w.t. alone. } \\
\text { Concept of self } \\
\text { Perfection can be } \\
\text { achieved along with } \\
\text { self-contentment } \\
\text { (mujahadah) }\end{array}$ & $\begin{array}{l}\text { Physiology } \\
\text {-Regarded as primary } \\
\text { or basic needs. } \\
\text {-This requirement is } \\
\text { located at the bottom } \\
\text { of the hierarchy of } \\
\text { Maslow's theory. } \\
\text { Safety safety } \\
\text { Among are } \\
\text { requirements stability, } \\
\text { security, } \\
\text { protection, and lack } \\
\text { of fear, anxiety and } \\
\text { chaos. } \\
\text { Social } \\
\text { Man on } \\
\text { companionship, } \\
\text { human relationships } \\
\text { and societal values. } \\
\text { Concept of self } \\
\text { That is the perception } \\
\text { or view of one who is } \\
\text { dependent } \\
\text { himself. }\end{array}$ & $\begin{array}{l}\text { Man needs some basic } \\
\text { necessities of life, } \\
\text { such as food, shelter } \\
\text { and others for } \\
\text { survival. }\end{array}$ \\
\hline
\end{tabular}


INTERNATIONAL JOURNAL OF ACADEMIC RESEARCH IN BUSINESS AND SOCIAL SCIENCES Vol. 8, No. 10, Oct. 2018, E-ISSN: 2222-6990 @ 2018 HRMARS

\begin{tabular}{|l|l|l|l|}
\hline Self-perfection & Self-perfection \\
- Essential perfection is & -This is the highest \\
only for Allah s.w.t. & level in Maslow's \\
-Self-actualization can & hierarchy needs. \\
be accessed through & -All levels of the \\
faith. & $\begin{array}{l}\text { underlying needs are } \\
\text { fulfilled. } \\
\text {-Ensure basic human } \\
\text { needs to achieve self- } \\
\text { realization. }\end{array}$
\end{tabular} \mid

\section{ACKNOWLEDGEMENT}

Special appreciations to the Research Management, Innovation \& Commercialization (RMIC), Universiti Sultan Zainal Abidin (UniSZA) \& the Faculty of Islamic Contemporary Studies (FKI, UniSZA) for sponsoring the project.

\section{REFERENCES}

Atiullah, M., Ismail, I., \& Abubakar, I. (2014). Kehendak Manusia: Justifikasi dan pengkategorian berdasarkan tanggungjawab. Jurnal Islamiyyat, 36(1), 57-62.

Baharom, N. (2007). Kamus dewan. (Ed. ke-4). Kuala Lumpur: Dewan Bahasa Dan Pustaka.

al-Ghazali, M. M. (1975). Ma'arij al-Quds fi madarij ma'rifah al-Nafs. Beirut: Dar al-Afaq al-Jadidah.

al-Ghazali, M. M. (2015). Ihya 'ulum al-Din. Cairo: al-Maktabah al-Tawfiqiyyah.

Hamat, M. F. (2002). Peranan akidah dalam perancangan pembangunan ummah: satu analisis dalam konteks masyarakat kini. Jurnal Usuluddin, 16, 13-34.

Hamid, S. A. (2012). Penghayatan agama sebagai motivasi keinginan pencapaian: Kajian usahawan Melayu Mara Kedah. (Tesis doktor falsafah yang tidak diterbitkan). Universiti Malaya, Kuala Lumpur.

Haris, A. W. (2010). Kesejahteraan sosial dan pembangunan komuniti: Pendekatan dan indakator. Seminar Serantau Islam dan Kesejahteraan Sejagat, Universiti Islam Sultan Sharif Ali, Brunei Darussalam.

Huitt, W. (2001). Motivation to learn: An overview in Educational psychology interactive. Valdosta: State University.

Maslow, A. (1970). Motivation and personality. New York: Harper \& Row Publisher.

Maslow, A. H. (2012). A theory of human motivation [e-book]. Accessed through https://books.goo gle.com.my/books.

Nor Nazimi Mohd Mustaffa, Jaffary Awang, \& Aminudin Basir@ Ahmad. (2017). Teori Maslow dan kaitannya dengan kehidupan muslim. Jurnal Hadhari, 9(2), 275-285

Omar S.H.S., Fadzli, A., Baru, R., Norhashimah, Y. (2017). Tok Ku Paloh's manual on sufi practices in Ma'arij Al-Lahfan Li Al-Taraqqi Ila Haqaiq Al-'irfan. Pertanika Journal of Social Sciences and Humanities 25(Special Issue), pp.1-11. 
INTERNATIONAL JOURNAL OF ACADEMIC RESEARCH IN BUSINESS AND SOCIAL SCIENCES

Vol. 8, No. 10, Oct. 2018, E-ISSN: 2222-6990 @ 2018 HRMARS

Zainal, K. (2008). Memahami tingkah laku remaja bermasalah dari persepektif teori tingkahlaku, humanitik, psikoanalitik \& tret personaliti. Jurnal Pengajian Umum, 9, 43-56, ISSN 1511-8393. 